Board of Governors of the Federal Reserve System

International Finance Discussion Papers

Number 666

May 2000

\title{
DEVIATIONS FROM PURCHASING POWER PARITY: CAUSES AND WELFARE COSTS
}

\author{
Charles Engel and John H. Rogers
}

NOTE: International Finance Discussion Papers are preliminary materials circulated to stimulate discussion and critical comment. References in publications to International Finance Discussion Papers (other than an acknowledgment that the writer has had access to unpublished material) should be cleared with the author or authors. Recent IFDPs are available on the Web at www.bog.frb.fed.us. 


\title{
DEVIATIONS FROM PURCHASING POWER PARITY: CAUSES AND WELFARE COSTS
}

\author{
Charles Engel and John H. Rogers*
}

\begin{abstract}
We explore deviations from short-run purchasing power parity (PPP) across European cities, attempting to move beyond a "first-generation" of papers that document very large border effects. We document two very distinct types of border effects embedded in relative prices. The first is a "real barriers effect", caused by various barriers to market integration. The second is a sticky-consumer-price cum volatile exchange-rate effect. Both are shown to be important empirically, the second type especially so. We argue that the two effects are very different from each other. For the first type of effect, it is clear that border effects imply deadweight welfare losses. We argue that while the second type of border effect could be eliminated with fixed exchange rates, welfare is not necessarily increased.
\end{abstract}

Keywords: exchange rates, borders, integration

*Engel is a Professor of Economics at the University of Washington, and affiliate of the National Bureau of Economic Research. He can be reached at Department of Economics, Savery Hall, University of Washington, Seattle, WA 98195. Rogers is an economist in the International Finance Division of the Federal Reserve Board, and can be reached at Mail Stop 22, Federal Reserve Board, Washington, D.C. 20551. Email: cmengel@u.washington.edu and john.h.rogers@frb.gov. The views in this paper are solely the responsibility of the authors and should not be interpreted as reflecting the views of the Board of Governors of the Federal Reserve System or of any other person associated with the Federal Reserve System. Engel acknowledges assistance from a grant by the National Science Foundation to the National Bureau of Economic Research. 
A spate of recent research has improved our understanding of the magnitude, sources, and implications of the well-documented deviations from the law of one price internationally (Isard, 1977). One strand of the literature estimates half-lives of real exchange rates. For most countries and time periods, real exchange rates are found to be highly persistent, with deviations from PPP among industrialized nations having half lives of three to four years. ${ }^{1}$ Another strategy has been to compare movements in goods prices across national borders to price movements between different regions within a country. Engel and Rogers (1996) (hereafter referred to as ER) demonstrate that prices of similar goods between U.S. and Canadian cities are systematically more variable than prices between equidistant cities in the same country. By this "width of the border" metric, international failures of the law of one price are large. The ER finding is consistent with other research showing that goods, labor, and capital flow more readily between regions within a country than across borders (see McCallum, 1995 and papers in the volume edited by Hess and Van Wincoop, 1999).

Several insights have also been brought to bear on the possible sources of these failures of the law of one price. The potential sources include tariffs and non-tariff barriers to trade, transportation costs, non-traded inputs such as marketing and other distribution services that are a part of final goods prices, and variable nominal exchange rates under sticky prices. One explanation of this last source is that producers selling abroad set prices in the currency of consumers rather than their own. Under local currency pricing (LCP), changes in nominal exchange rates do not affect goods prices in the local market, i.e., there is zero pass-through of exchange rate changes. Several papers present evidence of local currency pricing, including Giovannini (1988), Marston (1990), and Knetter (1993). Feenstra and Kendall (1997) find that a significant portion of observed deviations the law of one price is attributable to incomplete exchange rate pass-through as a result of local currency pricing. Our results are consistent with Feenstra and Kendall's.

Interest in the extent to which local currency pricing can account for empirical failures of the law of one price has surged for two related reasons. First, with the launching of the Euro on January 1, 1999 the currencies of European Monetary Union members became irrevocably fixed on their way toward eventually disappearing from circulation. Across the Atlantic, advocates of a "dollar bloc" have recently proposed that some combination of Argentina, Mexico, Ecuador and Canada relinquish their national currencies and adopt the U.S. dollar. This would replace current arrangements that have produced different degrees of exchange rate flexibility, as did EMU. There have also been calls for a Japanese yen bloc in Asia. Deviations from the law of one price would be reduced under such unified currency blocs if local currency pricing is indeed a significant factor.

Second, several recent theoretical papers have argued that assumptions concerning price-setting behavior can affect debate about the merits of fixed versus floating exchange rate systems. Engel (2000) and Devereux and Engel (1998) point out that traditional arguments in favor of floating rates all assume producer-currency pricing (PCP), where prices are set in the currency of the producer. Under $\mathrm{PCP}$, prices faced by consumers in an export market fluctuate with changes in the nominal exchange rate, so that there is complete pass-through of exchange rates to domestic prices; but, under localcurrency pricing (LCP), prices are set in the currency of the consumer and there is zero pass-through of exchange rates to local prices. Tille (1998) and Bachetta and Van Wincoop (1999) also consider pricesetting of this form, in dynamic general-equilibrium optimizing models, and highlight the role of deviations from the law of one price that result from different forms of price determination.

\footnotetext{
${ }^{1}$ See Rogoff's (1996) survey for references to this voluminous literature.
} 
In this paper we undertake an empirical exploration of failures of the law of one price across Europe. Our principal focus is the role of local currency pricing and floating exchange rates in accounting for international deviations from PPP. In ER, we suggest that local currency pricing may be an important factor in explaining the large border effect in consumer price data from U.S. and Canadian cities. The present study is a much more direct examination of local currency pricing than the earlier paper. ${ }^{2}$ We first investigate the determinants of the volatility of real exchange rates among cities in Europe. We estimate an equation that investigates deviations from relative PPP using consumer price data from European cities in 11 countries over the period 1981-97. The equation is similar to the one we estimated in ER. The dependent variable is the variance of changes in the log of real exchange rate across cities, and among the explanatory variables are distance and "border" dummy variables. The European data set has many advantages over that used in our earlier work. The ER data set consists of observations from U.S. and Canadian cities only. There is no distinction between the empirically-important border dummy (unity for city pairs lying across the border) and a measure of nominal exchange rate variability, since all cross-border pairs have the same nominal exchange rate. In the European data set we have city price data from several countries, and hence are able to include both a border dummy variable and a measure of nominal exchange rate variability in a regression explaining the variability of (common-currency) prices across cities. This allows us to assess the role of local currency pricing and variable nominal exchange rates directly rather than having to rely on the indirect methods used in ER. Our results indicate that most of the failures of the law of one price are attributable to local-currency pricing, but other barriers are also important explanatory factors. We find that, even taking into account nominal exchange rate variability, distance between cities and the border continue to have positive and significant effects on real exchange rate variability. However, these effects are small compared to the local currency pricing effect.

There is one important way in which the data in this study is less valuable than the consumer price data in ER. The city-level consumer-price data in Europe is available only for the aggregate consumer basket, while ER used city-level data on disaggregated categories of goods for U.S. and Canadian cities. ER employed data on fourteen broad sub-categories of goods, such as "food at home", "footwear", and "transportation." Here, we supplement our analysis of the European city data with country data on consumer prices that is more disaggregated. We have data for nine countries, for nineteen categories of goods. In some cases, the European country data is even more disaggregated than the data used in ER - with relatively narrow categories of goods such as books, sound and photographic equipment, and hotels - while other categories are at approximately the same level of aggregation as the ER data. The analysis with the disaggregated country data confirms our findings using the city-level data.

We briefly explore the welfare implications of our empirical findings. Devereux and Engel (1998) explore this issue extensively and methodically, but here we focus on a particular misconception about fixed exchange rates. When nominal prices are sticky in consumers' currencies, then nominal exchange rate fluctuations can lead to severe misalignment of goods prices between countries. There is inefficiency since consumers in different countries pay different prices for the same good. One may be tempted to infer from our regressions that the recent movement toward a world of fewer currencies would be associated with smaller welfare losses than would be implied by traditional

${ }^{2}$ Parsley and Wei (2000) is another approach to disentangling the local-currency-pricing effect from the real barriers effect. 
arguments in favor of national currencies and floating exchange rates. ${ }^{3}$ In other words, it might seem that fixed exchange rates are more desirable on the grounds that price deviations across borders are minimized, thus minimizing this inefficiency. This logic is not entirely correct. As in Devereux and Engel, under floating exchange rates and local-currency pricing, there is an economic inefficiency that results from consumers paying different prices in the two locations, even when transportation costs are zero. The law of one price holds if exchange rates are fixed and transport costs are zero, so that inefficiency is eliminated under fixed exchange rates. Even so, fixed exchange rates do not necessarily increase welfare because fixed rates imply a different monetary policy than under floating rates, which in turn implies different real outcomes (under sticky prices.) We produce an example where fixed exchange rates increase aggregate risk by increasing swings in world income. Thus, even if fixing exchange rates eliminated the welfare losses from failures of the law of one price, welfare is not necessarily improved. The inefficiency (and hence the welfare loss) is due to price stickiness, and the choice of the exchange rate regime does not necessarily alter that.

The paper attempts to move beyond the above-mentioned research that made the important contribution of documenting a "border" effect. There are two very distinct types of border effects embedded in relative prices. One is a sort of "real barriers effect", caused by various impediments to market integration. It is analogous to the border effects in the trade volume literature [e.g., McCallum (1995) and Helliwell (1996)]. This effect appears to be empirically significant in our European data set. The second is a sticky-consumer-price cum volatile exchange-rate effect. It is even more important empirically. We contend these two sources of deviations from the law of one price really cannot or should not be lumped together. For the first effect, it is clear that the border effect is associated with a deadweight welfare loss. The second effect is not so clear. Since a fixed exchange rate completely eliminates the second border effect, one might think that there is a deadweight welfare loss to floating exchange rates. We argue that is not true.

\section{Data}

We use consumer price indexes from 55 locations in Europe. ${ }^{4}$ The data are monthly, covering the period March 1981 to July 1997. Table 1 lists the locations. Notice that these span eleven countries. In four cases, Germany, Italy, Spain, and Switzerland, this includes price data from different locations within the country. The German data were obtained from the statistical offices of the individual Lander (state). The Italian data come from regular publications of the official government statistical agency ISTAT. For Spain, the data are on-line in the monthly statistical bulletin of Spain's national statistical institute INE, while the Federal Office for Statistics provided the data for Switzerland. We also use the CPI for Paris, which we obtained from the database of the Bank for International Settlements. For the other six countries--Austria, Belgium, Denmark, Luxembourg,

\footnotetext{
${ }^{3}$ The traditional arguments emphasize the benefits of autonomy in setting national monetary policies and the ease of relative price adjustment under floating rates. See the classic view put forth by Friedman (1953) and more recent contributions by Obstfeld (1997) and Feldstein (1997)

${ }^{4}$ Price data at a less aggregated level is not available on a comparable basis across these locations. At the end of the section, we use dis-aggregated European price data at the national level to show that our conclusions are robust. Engel (1999) has shown that essentially all of the variability in relative CPIs across countries is due to variability in traded-goods prices across countries, rather than variability in the ratio of non-traded to traded goods prices within countries.
} 
Netherlands, and Portugal--we were unable to obtain data from cities within the country. We rely on the national CPIs in those cases. These data were taken from the IMFs International Financial Statistics database, as were the nominal exchange rates used in the study.

Using price indexes from these 55 locations, we construct 1485 (=55 x 54/2) bilateral relative prices. In addition, our sample of eleven countries implies that the cross-border location pairs lie across one of 55 (=11 x 10/2) national borders (that are not necessarily adjacent).

There are a variety of arrangements determining the nominal exchange rates of our 55 countrypairs. Belgium and Luxembourg share a common currency. Germany was at the heart of the Exchange Rate Mechanism (ERM) of the European Monetary System, and so had a formal policy of fixed exchange rates with France, Austria, Belgium, Denmark, Luxembourg, and the Netherlands during the sample. Each of these countries was included in the first wave of entrants into the Euro, launched just after our sample ends. In contrast, Italy was a member of the ERM until 1992 (and later re-joined), while Spain and Portugal joined the ERM in 1994. There is also some variety in countries' participation in the free-trade area, the European Union (EU). Switzerland has remained out of any formal arrangements on either exchange rates or trade, while Spain and Portugal are relatively recent members of the EU, joining in the mid-eighties. All other countries were members at the beginning of our sample in 1981.

Related to these differences in formal participation in exchange rate arrangements are the different inflation performance of these countries. As seen from Table 1, average annual inflation rates range from 13 percent in Portugal, nearly 8 percent in Italy and Spain, to 3 percent or under in Germany, the Netherlands, and Switzerland. In spite of these cross-country differences in the period averages, the inflation rates of all countries converged noticeably over the sample, so that by 1996 inflation was less than 4 percent everywhere.

The eleven countries used in this study also differ along geographic, linguistic, and cultural lines. Germany, lying at the geographic center of Europe, shares a common border with seven of the other countries. On the other hand, Portugal and Denmark lie at the extremes, and share a common border with only one other country in the sample. We take explicit account of geographic considerations such as common border, as well as physical distance between locations. Finally, although languages are common to some extent across all countries, French and German are spoken in a relatively large number of countries in the sample, while Portuguese is rather specific to Portugal. These factors contribute, in varying degrees, to the openness of the countries. The final column of Table 1 displays one measure of openness, the imports-to-GDP ratio. These range from above ninety percent for Luxembourg to the low twenties for Italy, France, and Spain.

Our test might be called one of "proportional purchasing power parity" (PPPP) because our data is in the form of price indexes. We measure the standard deviation of changes in the $\log$ of the relative price (index) across locations $\mathrm{j}$ and $\mathrm{k}, \Delta p_{t}^{j}-\Delta p_{t}^{k}$. A finding that this measure of price variability is low indicates that percentage changes in goods prices in location $j$ relative to location $k$ are small. Numerically this could occur because (1) "absolute PPP holds", so that the difference in goods prices themselves in locations $j$ and $k$ is close to zero; (2) the price in one location $j$ is roughly proportional to the price in location $k$, so $p_{t}^{j}-p_{t}^{k}$ is nearly constant; or, (3) because $\Delta p_{t}^{j}$ and $\Delta p_{t}^{k}$ are nearly constant. Were we to use price levels rather than price indexes, we would be able to distinguish between these three possibilities. 


\section{Relative Prices: Summary Statistics}

Denote the $\log$ of the CPI in location $j$ relative to that in location $k$ as $P(j, k)$. All prices are denominated in U.S. dollars. We are interested in explaining the volatility of changes in $P(j, k)$. We consider one-month changes in relative prices, $\Delta P(j, k)$, but also examine the robustness of our results using 12-month and 48-month differences. We measure volatility as the variance. ${ }^{5}$

We construct a measure of volatility for each of our 1485 location-pairs. The analysis is then based on the cross-section of 1485 volatility measures. Table 2 presents summary statistics. The first row reports averages for all pairs of locations. In the rows that follow, we report averages for pairs of locations that are (i) both within Germany, (ii) both within Italy, (iii) both within Spain, (iv) both within Switzerland, (v) both within the same country (labeled intra-national), and (vi) one in one country and one in a foreign country (labeled inter-national).

The first column of Table 2 reports the average variance of $\Delta P(j, k)$, for three different horizons, 1-month, 12-months, and 48-months. For 1-month changes, the average volatility of crossborder pairs is 2.76 , more than sixteen times larger than the average variance of within-country pairs, 0.17. The within-Germany pairs exhibit the lowest average volatility, followed in order by those of Switzerland, Italy, and Spain. But even the volatility of relative price changes across Spanish cities, equal to 0.23 , is considerably lower than the average volatility of the cross-border pairs. At longer horizons, we observe a similar pattern: cross-border relative price changes are more volatile that intranational price changes by at least an order of magnitude.

The next column reports the volatility of nominal exchange rate changes, $\Delta s(j, k)$, again for horizons of 1-months, 12-months, and 48 months. For cross-border pairs, nominal exchange rate variability is practically identical to relative price variability, a result that is well established in the literature. For example, at the 48-month horizon the average volatility of cross-border relative price changes is 159.8 , while the average volatility of nominal exchange rate changes is 159.0. As seen in the next column, which reports the average distance between locations, we also see that cross-border pairs are typically more distant than the within-country pairs. In order to sort out the relative influence of these factors, we examine the regression evidence.

\section{Regression Specifications}

In the next section we present the results of our attempt to explain $V(\Delta P(j, k))$, the variance of $\Delta P(j, k)$. We estimate regressions of the form:

\footnotetext{
5 In past work, we have looked at the robustness to using root mean squared errors as an alternative measure of volatility. Because the drifts in relative price changes are all near zero, the results are essentially identical to those using variances. Also, in past work, we have taken the variance of the forecast error from AR regressions of the relative prices. In practice, because the relative prices are so persistent, there is little difference in the two approaches.
} 


$$
V(\Delta P(j, k))=\sum \alpha(m) D(m)+\beta_{1} r(j, k)+\beta_{2} r^{2}(j, k)+X \theta+u(j, k)
$$

where $D(m)$ is a dummy variable for each city in our sample, $r(j, k)$ is the distance between cities $j$ and $k$, and $X$ is a vector of explanatory variables that differ across different specifications. Note that all regressions are cross-sectional, with 1485 observations. The inclusion of separate dummies for each individual location allows the variance of price changes to vary from city to city. One reason for this comes from Table 2, which indicates somewhat higher average volatility for Spanish and Italian cities than German or Swiss cities. This could be because Spain, for example, is a relatively heterogenous country. Spain's labor markets or goods markets may be less integrated than those of Switzerland, so there can be greater discrepancies in prices between cities in Spain. Aggregate supply shocks may vary more across cities in Spain and Italy than Switzerland. Alternatively, there may be differences across countries in methodologies for gathering price data that lead to greater discrepancies in prices between locations in one country than another.

We use a couple of measures to proxy for the variation in expected transport costs. First, we hypothesize that this variance will be larger the greater the distance between locations. As in the gravity model of trade, we postulate a concave relationship between distance and relative price volatility, and so expect that $\beta_{1}>0$ and $\beta_{2}<0{ }^{6}$ We interpret "transportation costs" liberally to include any factors that make it more costly to sell in one location compared to another. For example, there may be trade barriers between countries. A large portion of the cost that consumers pay is for the marketing and distribution of the good. Producers may find it more costly to market in locations that are distant from where the production takes place and corporate decisions are made. Likewise, distribution networks may be more difficult to organize and monitor in distant locales.

The variables included in $X$ differ across specifications. We are particularly interested in whether there is a border effect. That is, even taking into account distance between two locations, and the nominal exchange rate variance, are there other factors that cause prices in cities in different countries to vary? For reasons outlined in the model above, and considering the results of Engel and Rogers (1996), we expect the variability of prices between cities that lie across a border to be higher than those between cities within a country, even after accounting for the effect of distance. Therefore, we include in $X$ a dummy variable, Border, that takes on a value of unity if cities $j$ and $k$ are in different countries. This dummy variable may capture some of the formal and informal international barriers to trade. We typically find Border to be positive and significant.

One reason the dummy variable Border might be important is because of local currency pricing by producers, as shown above. To test this, we include in $X$ the variance of nominal exchange rate changes between locations $j$ and $k, V(\Delta s(j, k))$. We stress the usefulness of including this variable in addition to the Border dummy. This allows us to assess the role of exchange rate variability / sticky prices directly. In Engel and Rogers (1996) we had to rely on indirect attempts to assess this channel. This is because in our earlier data set, where we had observations from U.S. and Canadian cities only, there is no distinction between the Border dummy variable and nominal exchange rate variability, since all cross-border pairs have the same nominal exchange rate. Including both regressors would be

${ }^{6}$ We also ran regressions with a logarithmic, rather than quadratic, functional form for distance. We found $\log ($ distance $)$ to be positive and significant, as we have in our earlier work. 
redundant in that data set. In the current case we have city price data from several countries, and hence are able to include both Border and $V(\Delta s(j, k))$.

There are of course reasons other than sticky prices why the border matters. Although there are no formal barriers to trade among most countries in the sample for most of the period (Switzerland is the exception), there may be informal barriers. Furthermore, marketing and distribution networks may be less homogenous across borders than within countries, perhaps in part because a different language is spoken in the foreign country. We consider how much of the variance of relative prices continues to be explained by the Border dummy once we have included nominal exchange rate volatility in the regression, as well as controls for language and a common border. Finally, we measure the importance of each of the several borders in our sample, by including in $X$ individual border dummies (e.g., Germany-Italy, Germany-Spain, etc.). ${ }^{7}$ The relative sizes of these may provide clues as to why the border effect is large, and allows us to go beyond what we were able to do in Engel and Rogers (1996).

\section{Regression Results}

The first column of Table $3 \mathrm{~A}$ presents the results of regressing the variance of the 1-month change in the log relative price on Distance, Distance squared, Border, and 55 individual location dummies (one for each of our 49 cities and for Austria, Belgium, Denmark, Luxembourg, Netherlands, and Portugal). All coefficients have the anticipated sign and are significant at the 5 percent level. The coefficient on the Border dummy is 2.85 with a standard error of 0.06 . The interpretation of this coefficient is the difference between the average variance of relative prices for city pairs that lie across a border less the average for pairs that lie within a country, taking into account the effect of distance and city-specific characteristics. The positive and significant estimated Border effect confirms the results for the U.S. and Canada documented by Engel and Rogers (1996): crossing an international border adds considerable volatility to relative city prices, even after accounting for the effects of distance and city-specific characteristics.

There are many possible explanations for the strong border effect, one of which emphasizes the role of local currency pricing in a world of variable nominal exchange rates. Specification 2 adds to the regression the variability of one-month nominal exchange rate changes, which of course is zero for all intra-national pairs. For our sample, the coefficient on nominal exchange rate variability is 0.92 . The fact that this is significantly less than unity (the standard error is 0.005) suggests that there is not complete local currency pricing (irrespective of the length of nominal price stickiness), as local prices respond somewhat to exchange rate changes.

Although nominal exchange rate variability does not magnify real exchange rate variability by as much as our model of local currency pricing implies, the addition of $V(\Delta s(j, k))$ substantially weakens the effect of the Border dummy, whose point estimate falls from 2.85 in specification 1 to 0.21 in specification 2. This suggests that a very large part of the border effect is from variable nominal exchange rates under sticky prices. However, even with $V(\Delta s(j, k))$ in the regression, the Border dummy remains positive and significant with a t-statistic exceeding 10 . In specification 3 , we add two dummies variables, Adjacent, which is unity if there is a common border separating the city

7 This necessitates dropping both Border and $V(\Delta(s(j, k)))$. 
pair and Language, which is unity if the cities lie in different countries that speak a common language. We hypothesize that each of these dummies will be negatively related to relative price variability. As seen in Table 3A, the adjacency dummy is negative and significant, while Language is insignificant. There is very little effect on the rest of the estimated coefficient.

It is interesting to compare the findings for Europe with results from similar regressions using the U.S/Canadian CPI data of ER (1996). In that case, when we estimate an equation similar to regression 1 in Table 3A, we find a coefficient on the border dummy of 2.68 with a standard error of 0.02 (compared to 2.85 with a standard error of 0.06 in regression 1.) The estimated border coefficients are very similar, but further investigation in the U.S./Canada case also points to nominal exchange rate volatility. Replicating regression 3 from Table 3A with CPI data from the U.S.-Canada sample used by ER (1996), we estimate a coefficient on exchange rate variability of 1.08 with a standard error of 0.007 (as compared to 0.92 with a standard error of 0.009 in regression 3.) In this regression, we omit the border dummy because it would be perfectly collinear with the exchange-rate variance variable (since there are only two countries involved.)

Specification 4 replaces the variance of the nominal exchange rate and the Border, Adjacency, and Language dummies with individual dummies for each border (Germany-Italy, Germany-Spain, ..., Netherlands-Portugal), of which there are 55 in our sample. ${ }^{8}$ Distance and distance squared remain of the expected sign and are significant in this specification. We also report the 5 largest and smallest of the 55 estimated individual border dummies. The smallest are Belgium-Luxembourg, GermanyAustria, Germany-Netherlands, Austria-Netherlands, and Denmark-Luxembourg. The largest are Italy-Switzerland, Spain-Switzerland, Switzerland-Portugal, Italy-Portugal, and Italy-Luxembourg. Notice that the largest border coefficient, 3.98 for Italy-Switzerland, is nearly 40 times larger than the smallest (0.11 for Belgium-Luxembourg).

What explains the relative sizes of these individual border effects? Nominal exchange rate variability certainly comes to mind. Even in our pre-Euro sample period, Belgium and Luxembourg shared a common currency and so have had zero nominal exchange rate variability. The currencies of Germany, Austria, and the Netherlands were tied together relatively closely. This may not be everything, however. According to Table 1, Belgium and Luxembourg are the two most open countries in our sample, as measured by imports-to-GDP ratio. Also, in the latter three countries, German is a commonly-spoken language; these three are also likely to experience similar supply shocks due to their geographic proximity and the similarity of their economic bases. At the other extreme, all five of the largest border dummies involve Italy and/or Switzerland. Switzerland is the only country in our sample that is not a member of the free-trade EU area. In addition, Switzerland did not participate in the exchange rate mechanism of the EMS (nor is it a prospective EMU member) and so has experienced relatively large fluctuations in the value of its currency.

Figure 1 presents a scatter plot of the estimated border coefficients against the variance of the nominal exchange rate. The tight, positive relationship that is evident from the plot confirms our earlier evidence on the importance of nominal exchange rate variability.

8 With $n=11$ countries, there are $[n *(n-1) / 2]=55$ individual border dummies. 
Figure 2 plots the border coefficients against a frequently-used measure of openness to trade, the average imports-to-GDP ratio of the two countries. Table 1 lists this ratio for each country in the sample. Note that this measure only partially coincides with a priori beliefs about the degree of barriers to bilateral trade. For example, trade between France and Italy, two original members of the European Union, is by all accounts more open than trade between Portugal and Switzerland. But, the trade openness measure for the France-Italy pair is .21, which is less than the value of .365 for Switzerland-Portugal. Because things such as geographical factors are important in determining a country's import/GDP ratio above and beyond the influence of formal trade barriers, one should think of the horizontal axis in Figure 2 as reflecting how open the economies are on average. ${ }^{9}$ Ocular inspection reveals some evidence of a negative relationship between the size of the border effect and the imports/GDP ratio, but one that is not nearly as tight as in Figure 1.

We also undertook two additional robustness checks. First, we reproduced Figures 1 and 2 using the border coefficients from the regression estimated with 48-month changes. The relationship between nominal exchange rate variability and the border coefficients remains positive and significant at the 48-month horizon, although it is not as tight as at 1 month. On the other hand, there still appears to be no relationship between the estimated border coefficients and "openness" at the 48-month horizon. Second, we incorporated two different measures of changes in relative tax rates across countries. The first measure uses the value-added tax (VAT) rate, while the second uses consumption tax revenue as a share of GDP, in each case the difference between the rate at the end of the sample less that in 1980. The idea is to see if PPP holds better for countries whose tax structures have become more similar over time. In general, there was some convergence of tax rates in our sample. The standard deviation of the VAT rate across the 11 countries fell from $8.1 \%$ to $4.5 \%$ from the beginning to end of the period, while that of the consumption tax measure fell from $3.1 \%$ to $2.6 \%$. According to the hypothesis, we should see a positive relationship between the tax change variable and the border coefficients. However, in scatter plots analogous to Figures 1 and 2, we find no relationship at all. These figures are available on request.

The three specifications in Table 3B repeat the regressions of specifications 1,3 and 4 , but using 48-month changes instead of one-month changes in relative prices and exchange rates. The effects of the Border dummy and nominal exchange rate variability are comparable to those reported in the earlier specifications. However, distance becomes slightly less significant. For example, in specification 2 distance is insignificantly different from zero in the case of the 48-month changes, but has a t-statistic of around five in the one-month case. This result is interesting because it suggests that the effects of transportation costs, and not those of local currency pricing, tend to diminish at longer horizons (to the extent that distance proxies for transportation costs).

\section{Analysis of the Sub-Periods}

The results so far were all computed over the full sample period, 1981:3-1997:7. Table 4 presents summary statistics for three different sub-periods: 1981:3-86:12, 1987:12-92:7, and 1992:11-

\footnotetext{
9 There are alternatives to using the imports-to-GDP ratio in our calculation of trade openness. Direct measures of trade barriers are periodically compiled by the United Nations Commission on Trade and Development (UNCTAD). These country-wide measures are constructed using, e.g., the average tariff rate or the percentage of goods which are subjected to some type of non-tariff barrier. Also, Harrigan (1996) presents model-based estimates of openness in manufacturing trade among OECD nations. However, Switzerland is not included in Harrigan's group of countries.
} 
97:7, and regression results for the 1987:12-92:7 sub-period. The sub-periods correspond roughly to the changing fortunes of the ERM. The so-called Hard-EMS period began in 1987 after some turbulence in foreign exchange markets in the early to mid-1980s. This period witnessed no realignments of official parities. However, the general calm in the foreign exchange market was broken abruptly in September 1992, when the U.K. and Italy withdrew from the ERM.

The first panel of Table 4 presents the average $V(\Delta P(j, k))$ and $V(\Delta s(j, k))$ for the three subperiods and the full sample. The variability of relative price changes for within-country pairs falls noticeably across the sub-periods. The average for all intra-national pairs, for example, falls from 0.22 in the pre-1987 sub-period to 0.16 in the Hard-EMS period, to 0.07 post-1992. This decline is evidence of increased economic integration within countries, which is likely to be caused by advancements in transportation, communication, etc. Despite the apparent increased integration within countries, there is no tendency toward increased convergence of inter-national relative prices, as indicated by the average variances of $2.30,1.06$, and 3.65 for the three sub-periods. Instead, this pattern follows that of nominal exchange rate variability, as displayed in the final columns of the panel. The average variance of the nominal exchange rate change for our three sub-periods is $2.18,0.71$, and 3.62 .

These summary statistics cast doubt on the hypothesis that our results from Table $3 \mathrm{~A}$ arise from reverse causality - that nations stabilize nominal exchange rates when the real barriers separating them fall. The shift in the variance of the nominal exchange rate from sub-period 1 to 2 can be interpreted as an exogenous event, as part of a political process aimed ultimately at European Monetary Unification. The size of the real exchange rate variance appears to have fallen as a result of the decline in nominal exchange rate variance, rather than vice-versa. ${ }^{10}$

The bottom panel of Table 4 presents regression results for the Hard-EMS sub-period. We choose this period since it is associated with significantly lower variability in nominal exchange rates. We repeat specifications 1,2, and 4 from Table 3A. Distance is notably smaller and less significant than in the full sample. The estimated Border coefficient is still positive and significant, but is only about one-third its size of the full sample regressions. This suggests that the forces leading to greater market integration of different regions within countries are at work to an even greater extent between countries. Finally, the individual Border effects shown in specification 3 are considerably smaller than in the full sample.

\section{Analysis of Disaggregated Data at the National Level}

The results so far have been for overall CPI data. It would be interesting to know whether we find similar results using highly disaggregated goods prices. Unfortunately, such data do not exist for the locations in the above sample. However, it would be very surprising if the evidence of deviations

\footnotetext{
${ }^{10}$ It can be argued, contrary to the interpretation above, that real shocks are the dominant influence affecting the ability of monetary authorities to stabilize nominal exchange rates, and that the severity of these shocks changed across sub-periods. However, it seems more reasonable to interpret our results for sub-periods 1 and 2 as driven by an exogenous attempt by the monetary authorities to reduce nominal exchange rate variability, which lead to a reduction in real exchange rate variability. It is more problematic to argue for a similar interpretation of the results for sub-periods 2 and 3 . Ultimately, the issue boils down to parsing out the contributions of real and monetary shocks on exchange rate fluctuations. Although this is beyond the scope of the present paper, Rogers (1999) and Faust and Rogers (1999) provide recent analyses.
} 
from purchasing power parity across cities that we have examined here does not mostly reflect failures of the law of one price. Engel (1993, 1999) and Rogers and Jenkins (1995) present compelling evidence that the dominant determinant of real exchange rate movements (at least for rich countries) is failure of the law of one price, rather than some relative price movements (such as changes in the price of traded to nontraded goods.)

Appropriate data is available at the national level, however. In this section, we undertake an analysis similar to that above to explain the cross-section of deviations from the law of one price at the national level for dis-aggregated goods.

Our sample consists of monthly price data from nine European countries over the period 1977 to $1995 .^{11}$ We look at 19 components of the CPI. Some of these are relatively homogenous goods such as meat, footwear, or books. Others represent broader categories such as food or clothing. We follow the procedure outlined above. First, for each good we construct the common-currency relative price across all country-pairs, the variance of the 12-month difference in the relative price is our proxy for volatility. We choose to use 12-month differences here as a compromise between our very shortterm (1-month) and much longer term (48-month) regressions with the city data. Second, we explain the volatility of those price changes in terms of distance between locations, an adjacency dummy and country dummies, and the volatility of nominal exchange rate changes.

The results are depicted in Table 5. For 18 of the 19 goods, the coefficient on nominal exchange rate volatility is positive and statistically significant. Most of the estimated coefficients are close to unity. Two exceptions to this are Fruit, with a coefficient of 0.25 , and Fuel and Energy, with a coefficient of 0.41 . The fact that these coefficients are relatively small is reminiscent of Engel's (1993) conclusion on U.S./Canadian data. That paper found that for most goods, there were significant deviations from the law of one price at the consumer level. But the exception to that was those consumer goods that were more like pure commodities (such as fruit or fuel), rather than more complex consumer products.

The coefficients on distance, distance squared, and adjacency were generally of the correct sign but statistically insignificant. We do not report them in order to save space. It is probably not surprising that these variables do not perform as well using the country data. The measurement of distance is much more ambiguous when dealing with countries as compared to cities.

The results from this disaggregated data suggest that our conclusions from the preceding sections are largely robust. Variance in relative goods prices is closely related to the variance of nominal exchange rates.

\section{The Deadweight Loss from Law of One Price Deviations}

When consumers pay different prices for identical goods, there appears to be deadweight loss to the economy. If our conclusions from the data are correct - that there are failures of the law of one price in Europe that arise principally from local-currency pricing and variable exchange rates - then

\footnotetext{
${ }^{11}$ The data were obtained from Eurostat. There were some data errors in the Eurostat data that were cleaned. See Engel (2000) for a more detailed description of the data, and the data cleaning. Table 5 also provides more details of the data.
} 
currency union would eliminate an important economic inefficiency. But, fixing exchange rates or adopting a single currency has implications beyond the fact that it might eliminate inefficient differences in prices. Exchange rate policy is, at bottom, monetary policy. Particularly in a world of nominal price stickiness, there are real macroeconomic implications for the choice of monetary regime. Put another way, one cannot simply consider the partial equilibrium efficiency aspects of fixing exchange rates. To consider what the ramifications of pegging exchange rates are, one must analyze the exchange rate regime in general equilibrium. Here, our objective is to provide some simple intuition of what the general equilibrium tradeoffs are when we eliminate deviations from the law of one price by fixing exchange rates. We base our intuition on one of the models examined by Devereux and Engel (1998).

Devereux and Engel construct two-country, general equilibrium models with sticky nominal prices, in which households and firms optimize over an infinite horizon in an environment of uncertainty. Their models are in the vein of the "new open-economy macroeconomics" as exemplified by Obstfeld and Rogoff $(1995,1998)$. Devereux and Engel's contribution is to examine the choice of exchange-rate regime under different assumptions about the type of price stickiness. Here, we shall develop intuition based on their simple closed-form model of local-currency pricing.

For space considerations, we will not present the model in detail, and will refer the reader to Devereux and Engel (1998) for details. We will discuss the assumptions of the model, and present a few salient equations.

First, we consider the model of household behavior. In each country, the representative household maximizes expected utility over an infinite horizon. Utility is time-separable, and separable in three components: consumption, real balances and leisure. We will restrict attention to the simplest example considered by Devereux and Engel. In that example, leisure enters utility linearly, and real money balances logarithmically. Home country consumers get utility from their own leisure, and from holdings of home-country real balances. Real balances are defined as nominal money divided by the exact price index for consumption goods.

The structure of consumption preferences is intricate, and is assumed to be identical for home and foreign country residents. There is a continuum of goods produced in the home country, and a continuum produced in the foreign country. The elasticity of substitution among all home country goods (and among all foreign country goods) is a constant, $\lambda$, which is greater than one. Homecountry goods as an aggregate have a unitary elasticity of substitution with foreign-country goods (i.e., a Cobb-Douglas function for home and foreign country aggregates.) Let $C$ be the consumption index that is a geometric average of home and foreign consumption. The utility function for $C$ is of the constant-relative-risk-aversion form, with $\rho$ the coefficient of relative risk aversion.

So, felicity at time $t$ can be written as:

$$
u_{t}=\frac{C_{t}^{1-\rho}}{1-\rho}+\chi \cdot \ln \left(M_{t} / P_{t}\right)-\eta L_{t}
$$

Here, $L$ is the amount of work effort per household, $M$ represents holdings of money balances, and $P$ is the aggregate price level. 
There are $n$ households in the home country and $1-n$ households in the foreign country. Home goods receive a weight of $n$ in the utility function for goods.

Firms are monopolistic. Each firm sells to both home and foreign-country residents. Each unit of output is produced with a single unit of labor. Prices must be set one period in advance. Firms set a price in domestic currency terms for home residents and in foreign currency for foreign consumers. Firms face a competitive labor market, and are wage-takers. Firm managers maximize the expected utility of firm owners.

As the literature explains, ${ }^{12}$ the optimal price set by producers is not simply a mark-up over expected costs. It is a more complicated expression that involves the covariance of quantity sold and costs with the marginal utility of consumption. In part, these expressions arise from the fact that riskaverse households own firms, so that the optimal pricing rule must take into account non-diversifiable risk facing households.

Under floating exchange rates, the log of the money supply in each country follows a random walk. Shocks to each money supply may be independent, or may be correlated. Under fixed exchange rates, the foreign country still allows its money supply (in logs) to follow an independent random walk, but the home country must devote its monetary policy to maintaining a fixed exchange rate. In the example we are considering, monetary shocks are the only source of uncertainty in the economy. Monetary shocks are assumed to be lognormally distributed.

We follow Devereux and Engel in assuming there are a complete set of nominal contingent claims. That is, a nominal asset indexed to each possible state of nature is traded. But, the contract is settled in the currency of one of the countries. This enforces the restriction that home country residents must pay for goods in prices that are set in the home currency, and foreign country residents must pay for goods in prices set in the foreign currency. We do not allow any sort of real contingent contract that allows households to avoid paying the nominal goods price that is set by firms. This is a very traditional type of assumption in international macroeconomics - that asset markets function efficiently, but there is stickiness in goods markets.

In equilibrium, the optimal risk-sharing condition is:

$$
\frac{C_{t}^{-\rho}}{P_{t}}=\frac{C_{t}^{*-\rho}}{S_{t} P_{t}^{*}} .
$$

This equation has the interpretation that the marginal utility of a unit of the home currency is equal for home and foreign residents. $S_{t}$ is the home currency price of foreign currency, and starred variables are foreign-country quantities.

The special set of assumptions on preferences, along with the assumption of random-walk money, gives us a simple relationship between consumption and real balances in equilibrium:

12 See Obstfeld and Rogoff (1998), Bacchetta and van Wincoop (1998) and Devereux and Engel (1998) 


$$
C_{t}^{\rho}=\left(\frac{1-\mu \beta}{\chi}\right) \frac{M_{t}}{P_{t}}
$$

An identical equation holds in the foreign country. $\mu$ is the inverse of the geometric growth rate of money, $\beta$ is the utility discount factor. Nominal interest rates turn out to be constant in equilibrium in both countries in this example. This is a well-known outcome when real balances enter utility logarithmically, and log money supplies follow a random walk. ${ }^{13}$

Equations (2) and (3), along with the foreign-country counterpart of equation (3) imply, assuming identical parameters in the home and foreign country:

$$
S_{t}=\frac{M_{t}}{M_{t}^{*}}
$$

The exchange rate depends only on relative money supplies. If the home country wants to fix its exchange rate relative to the foreign country, it simply adopts an identical monetary policy.

The optimal relative price for home consumers set by home firms $\left(P_{h t} / P_{t}\right)$ and by foreign firms $\left(P_{f t} / P_{t}\right)$ is identical and given by:

$$
\frac{P_{h t}}{P_{t}}=\frac{P_{f t}}{P_{t}}=\frac{\lambda \eta}{\lambda-1} \frac{E_{t-1}\left(C_{t}\right)}{E_{t-1}\left(C_{t}^{1-\rho}\right)}
$$

In equilibrium, $P_{h t}=P_{f t}=P_{t}$, so equation (5) defines a relation between $E_{t-1}\left(C_{t}\right)$ and $E_{t-1}\left(C_{t}^{1-\rho}\right)$.

Since variables are assumed to be lognormally distributed, there are only two moments that describe the entire distribution - the mean and the variance. The implication of equations (2) and (5) in equilibrium is that the moments of consumption are a function only of the variance of the money supply. From the Appendix of Devereux and Engel, we get that expected utility of consumption is given by:

$$
\frac{1}{1-\rho} E\left(C^{1-\rho}\right)=\left(\frac{\lambda-1}{\eta \lambda}\right)^{1-\rho / \rho} \exp \left(\frac{\rho-1}{2 \rho^{2}} \sigma_{m}^{2}\right)
$$

Utility from leisure in the home country is equal to the expected output of the home country. Expected output depends on expected consumption levels in the home country and the foreign country. Hence, it depends on the variance of the home money supply (which determines home demand for home goods) and the variance of the foreign money supply (which determines foreign demand for home goods.)

13 See Obstfeld and Rogoff (1996). 
The expected utility terms involving consumption and leisure (we shall follow the literature and ignore the utility from real balances) depends on the variance of home and foreign money shocks, but not on their correlation. One implication is that the welfare comparison between floating in the symmetric case (equal variance of home and foreign money supplies) to utility under fixed exchange rates (the home money supply is equal to the foreign money supply) depends only on monetary variance under the two systems. If money supply shocks have the same variance under fixed and floating exchange rates, then welfare is equal under the two exchange-rate systems.

This result depends on some special assumptions we have made here. Our utility function is a special case of the more general formulation in Devereux and Engel (1998). Van Wincoop and Bacchetta (1999) have even more general welfare functions in a two-period model of local-currency pricing. But this simple model is perfect for illustrating a point we wish to emphasize. Under floating exchange rates and local-currency pricing, there is clearly an economic inefficiency because consumers are paying different prices in the two locations even when transportation costs are zero. The law of one price holds if exchange rates are fixed and transport costs are zero, so that inefficiency is eliminated under fixed rates. Even so, fixed exchange rates do not necessarily increase welfare.

Intuitively, under floating exchange rates expected utility is diminished because of the pricing inefficiency. Since residents in different locations face different prices under some states, there is idiosyncratic risk in equilibrium. The risk-sharing condition, equation (5), is identical to the condition derived by Backus and Smith (1993) in their model with non-traded goods. Aggregate consumption levels are not equalized in all states because consumers face different aggregate price levels. Under fixed exchange rates in this model, the law of one price holds and idiosyncratic risk is eliminated in equilibrium. Equation (5) shows that when the law of one price (and, hence, purchasing power parity) holds, consumption is equal at home and abroad in all states. But, fixed exchange rates increase aggregate risk. Monetary policies at home and abroad are perfectly correlated under fixed exchange rates. Since, in sticky-price models, swings in the money supply affect output, swings in world income are enhanced under fixed exchange rates. The trade-off, then, is that fixed exchange rates eliminate idiosyncratic risk at the cost of increasing aggregate risk. In this model, those two effects exactly cancel (if the monetary variances are the same under fixed and floating), so welfare is the same under the two exchange-rate systems.

Suppose money (and therefore consumption) in each country could take on only two values, high $(\mathrm{H})$ and low $(\mathrm{L})$. Under floating exchange rates, let us suppose there are four possible states, each equally likely. State 1 is $\mathrm{H}-\mathrm{H}$ (that is high home consumption, high foreign consumption). State 2 is $\mathrm{H}-\mathrm{L}$; state 3 is L-H; and, state 4 is L-L. Given that the exchange rate is just proportional to the money supplies (equation (4)), in states 1 and 4 the law of one price holds even though prices are preset. But in states 2 and 3, there are deviations from the law of one price. In those states, a planner could reallocate goods to improve worldwide welfare in the Pareto sense.

Now, suppose that under fixed exchange rates the home country alters its money supply to keep it equal to the foreign money supply in all states. So, state 1 is $\mathrm{H}-\mathrm{H}$; state 2 is L-L; state 3 is $\mathrm{H}-\mathrm{H}$; and, state 4 is L-L. There is no change in the allocations in states 1 and 4 . But now in states 2 and 3 the money supplies and consumption levels are equal, and the law of one price holds. Has welfare been improved? Clearly not (at least from looking at the consumption part of the utility function.) The mean and variance of consumption in both countries are exactly the same as under floating exchange rates. There is no pricing inefficiency under fixed exchange rates, but there is greater variance in world consumption. 
The choice of monetary regime affects the amount of aggregate risk in the economy. While fixed exchange rates eliminate the pricing inefficiency (in other words, eliminate the idiosyncratic risk in states 2 and 3), they increase the variance of aggregate average world consumption. The underlying inefficiency here is the stickiness of prices. That inefficiency cannot be eliminated by the choice of exchange-rate system.

This has direct implications for the interpretation of our empirical results. We find that the large border effect can be primarily attributed to the volatility of nominal exchange rates. If the border effect declines because exchange rates become permanently fixed, that does not necessarily imply that welfare will increase. The only clear-cut welfare improvement that accompanies reductions in law-ofone-price deviations comes from the reduction of real barriers to trade.

It is fair to say that one of the principle motivations for forming the EMU and moving to a single currency is that member countries hoped that some discipline might be imposed on their own monetary policies. If indeed the EMU succeeds in reducing overall monetary variance, then it will have a beneficial welfare effect.

\section{Conclusions}

We explore failures of the law of one price across European cities, using consumer price data from European cities over the period 1981-97. We attempt to move beyond a "first-generation" of research papers (by us and others) that empirically document very large border effects. There are two distinct types of border effects embedded in relative prices. The first, a "real barriers effect" caused by incomplete market integration, is analogous to the border effects in the literature on trade volumes. The second is a sticky-consumer-price cum volatile exchange-rate effect.

We attempt to identify the sources of the large border effects in international comparisons of consumer prices. Because of our unique data set on consumer prices from 55 locations across 11 European countries, we are able to identify that most of the border effects are coming from local currency pricing with fluctuating nominal exchange rates. Our results thus provide support for the focus on local currency pricing taken in several recent theoretical papers examining the welfare implications of different exchange rate regimes.

We find that even taking into account nominal exchange rate variability (as well as language and geographic considerations), the border still has a positive and significant effect on real exchange rate variability. However, these effects are small compared to the local currency pricing effect. We speculate that the remaining border effect reflects factors like cross-country differences in the national marketing and distribution systems. In addition, we confirm earlier findings that distance and cityspecific factors are also significant.

Finally, we link our empirical findings to Devereux and Engel's (1998) welfare results on fixed versus floating exchange rates. In the model, failures of the law of one price imply welfare losses due to inefficiency associated with consumers in different locations paying different prices for the same good. Our empirical work attributes most of the failure of the law of one price to local currency pricing and floating exchange rates. But even if failures of the law of one price were eliminated through fixed exchange rates, welfare is not necessarily improved. 


\section{References}

Bacchetta, Philippe and Eric van Wincoop, 1998, Does exchange rate stability increase trade and capital flows?, Federal Reserve Bank of New York, working paper no. 9818.

Bacchetta, Philippe and Eric van Wincoop, 1999, Does exchange rate stability increase trade and welfare?, Federal Reserve Bank of New York, mimeo.

Backus, David K., and Gregor W. Smith, 1993, Consumption and real exchange rates in dynamic economies with non-traded goods, Journal of International Economics 35, 297-316.

Baxter, Marianne, and Alan C. Stockman, 1989, Business cycles and the exchange-rate regime: Some international evidence, Journal of Monetary Economics 23, 377-400.

Devereux, Michael B. and Charles Engel, 1998, Fixed vs. floating exchange rates: How price setting affects the optimal choice of exchange-rate regime, National Bureau of Economic Research, working paper no. 6867.

Engel, Charles, 1993, Real exchange rates and relative prices: An empirical investigation, Journal of Monetary Economics 32, 35-50.

Engel, Charles, 1999, Accounting for U.S. real exchange rate changes, Journal of Political Economy $107,507-538$.

Engel, Charles, 2000, Local-currency pricing and the choice of exchange-rate regime, European Economic Review, forthcoming.

Engel, Charles and John H. Rogers, 1996, How wide is the border?, American Economic Review 86, 1112-1125.

Faust, Jon and John H. Rogers, 1999, Monetary policy's role in exchange rate determination, IFDP \#652, Board of Governors of the Federal Reserve.

Feenstra, Robert and Jon Kendall, 1997, Pass-through of exchange rates and purchasing power parity, Journal of International Economics 43, 237-261.

Feldstein, Martin, 1997, The political economy of the European Economic and Monetary Union: political sources of an economic liability, Journal of Economic Persepctives, 11, 23-42.

Giovannini, Alberto, 1988, Exchange rates and traded goods prices, Journal of International Economics 24, 45-68.

Harrigan, James, 1996, Openness to trade in manufactures in the OECD, Journal of International Economics 40, 23-40.

Helliwell, John, 1996, Do national borders matter for Quebec's trade?, Canadian Journal of Economics 29, 507-522. 
Hess, Gregory and Eric van Wincoop, eds., 1999, Intra-national macroeconomics, Cambridge University Press.

Isard, Peter, 1977, How far can we push the law of one price?, American Economic Review 67, 942948.

Knetter, Michael, 1993, International comparisons of pricing to market behavior, American Economic Review 83, 473-486.

Marston, Richard, 1990, Pricing to market in Japanese manufacturing, Journal of International Economics 29, 217-236.

McCallum, John, 1995, National borders matter: regional trade patterns in North America, American Economic Review 85, 615-623.

Obstfeld, Maurice, 1997, Europe's gamble, Brookings Papers on Economic Activity, no. 2, 241-317.

Obstfeld, Maurice and Kenneth Rogoff, 1996, Foundations of International Macroeconomics (Cambridge: MIT Press).

Obstfeld, Maurice and Kenneth Rogoff, 1998, Risk and exchange rates, National Bureau of Economic Research, working paper no. 6694.

Parsley, David, and Shang-Jin Wei, 2000, Border, border, wide and far, how we wonder what you are, Journal of International Economics, forthcoming.

Rogoff, Kenneth, 1996, The purchasing power parity puzzle, Journal of Economic Literature 34, 647668.

Rogers, John H. and Michael Jenkins, 1995, Haircuts or hysteresis? Sources of movements in real exchange rates, Journal of International Economics 38, 339-360.

Rogers, John H., 1999, Monetary shocks and real exchange rates, Journal of International Economics 49, 269-288.

Tille, Cedric, 1998, The international and domestic welfare effects of monetary policy under pricingto-market, working paper, Federal Reserve Bank of New York. 
Table 1 -- Locations of CPI Data

\begin{tabular}{|c|c|c|c|c|}
\hline Country: & Location & f Price Index used & Avg. Inflation & Imports/GDP \\
\hline Germany & $\begin{array}{l}\text { Baden-Wurttemberg } \\
\text { (Stuttgart) } \\
\text { Bavaria (Munich) } \\
\text { Berlin }\end{array}$ & $\begin{array}{l}\text { Hesse (Frankfurt) } \\
\text { Nordrein-Westf. (Dusseldorf) } \\
\text { Saarland (Saarbrucken) }\end{array}$ & 2.85 & 0.27 \\
\hline Italy & $\begin{array}{l}\text { Ancona } \\
\text { Aosta } \\
\text { Bari } \\
\text { Bologna } \\
\text { Cagliari } \\
\text { Campobasso } \\
\text { Florence } \\
\text { Genoa } \\
\text { L'Aquila } \\
\text { Milan }\end{array}$ & $\begin{array}{l}\text { Naples } \\
\text { Palermo } \\
\text { Perugia } \\
\text { Potenza } \\
\text { Reggio Calabria } \\
\text { Rome } \\
\text { Turin } \\
\text { Trento } \\
\text { Trieste } \\
\text { Venice }\end{array}$ & 7.90 & 0.20 \\
\hline Spain & $\begin{array}{l}\text { Andalucia (Seville) } \\
\text { Aragon (Zaragoza) } \\
\text { Baleares (Palma) } \\
\text { Canarias } \\
\text { Cantabria (Santanda) } \\
\text { Castilla la Mancha } \\
\text { (Toledo) } \\
\text { Castilla y Leon (Leon) } \\
\text { Cataluna (Barcelona) } \\
\text { Ceuta y Melilla (Ceuta) }\end{array}$ & $\begin{array}{l}\text { Comunid. Valencia (Valencia) } \\
\text { Extremadura (Badajoz) } \\
\text { Galicia (La Coruna) } \\
\text { La Rioja (Logrono) } \\
\text { Madrid } \\
\text { Murcia } \\
\text { Navarra (Pamplona) } \\
\text { Pais Vasco (Vizcaya) } \\
\text { Principado Asturias (Gijon) }\end{array}$ & 7.69 & 0.21 \\
\hline Switzerland & $\begin{array}{l}\text { Basle } \\
\text { Bern }\end{array}$ & $\begin{array}{l}\text { Geneva } \\
\text { Zurich }\end{array}$ & 3.17 & 0.34 \\
\hline France & Paris & & 4.80 & 0.22 \\
\hline Austria & Austria (Vienna) & & 3.33 & 0.38 \\
\hline Belgium & Belgium (Brussels) & & 3.76 & 0.66 \\
\hline Denmark & Denmark (Copenhagen) & & 4.46 & 0.32 \\
\hline Luxembourg & Luxembourg & & 3.75 & 0.92 \\
\hline Netherlands & Netherlands (The Hague) & & 2.52 & 0.50 \\
\hline Portugal & Portugal (Lisbon) & & 13.3 & 0.39 \\
\hline
\end{tabular}

Notes: The table lists the locations for our data on consumer price indexes. In those cases in which prices are taken from a state (as in Germany), region (as in Spain), or from the country as a whole, the city listed in parenthesis is that used to calculate distances. All data are monthly from 1981:3-1997:7.

Inflation rates and import-to-GDP ratios are annual averages over the period 1981-96. 
Table 2; Summary Statistics

\begin{tabular}{ccccccccc}
\hline \hline Pairs: & \multicolumn{3}{c}{ Variance $\Delta P(j, k)$} & \multicolumn{3}{c}{ Variance $\Delta s(j, k)$} & Distance & \# obs. \\
& 1 -mo. & 12 -mo. & 48 -mo. & 1 -mo. & 12 -mo. & 48 -mo. & & \\
\hline All & 2.12 & 39.7 & 121.3 & 1.97 & 40.1 & 120.0 & 653 & 1485 \\
GE-GE & 0.02 & 0.21 & 1.24 & 0.00 & 0.00 & 0.00 & 209 & 15 \\
IT-IT & 0.14 & 0.99 & 2.80 & 0.00 & 0.00 & 0.00 & 263 & 190 \\
SP-SP & 0.23 & 1.01 & 3.08 & 0.00 & 0.00 & 0.00 & 417 & 153 \\
SW-SW & 0.07 & 0.37 & 1.56 & 0.00 & 0.00 & 0.00 & 80 & 6 \\
intra-national & 0.17 & 0.96 & 2.83 & 0.00 & 0.00 & 0.00 & 322 & 364 \\
inter-national & 2.76 & 52.3 & 159.8 & 2.62 & 53.1 & 159.0 & 760 & 1121 \\
\hline \hline
\end{tabular}

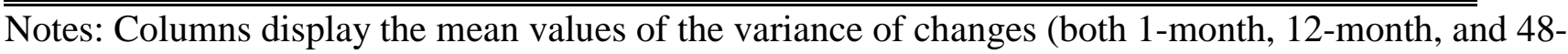
month changes) in the relative price between location $\mathrm{j}$ and $\mathrm{k}, \Delta \mathrm{P}(\mathrm{j}, \mathrm{k})$, and the change in the nominal exchange rate $\Delta \mathrm{s}(\mathrm{j}, \mathrm{k})$, distance (in miles), and the number of observations. Prices are in U.S. dollars. Listed by row is the sample of cities used in the calculations. The first row uses city pairs in all 55 locations; GE-GE indicates that only the within-Germany city pairs are used; IT-IT, SP-SP, and SWSW are the analogies for the Italian, Spanish, and Swiss cities; intra-national indicates that only pairs of cities within countries are used; and inter-national indicates that only cross-border pairs are used in the calculations. The data are monthly from 1981:3-1997:7. 
Table 3A; Regressions Explaining Relative Price Variability

\begin{tabular}{ccccc}
\hline \hline Specification: & 1 & 2 & 3 & 4 \\
\hline Distance $^{1}$ & $5.20^{*}$ & $1.05^{*}$ & $0.88^{*}$ & $0.81^{*}$ \\
& $(1.28)$ & $(0.21)$ & $(0.21)$ & $(0.21)$ \\
Distance Squared $^{2}$ & $-3.12^{*}$ & $-0.52^{*}$ & $-0.49^{*}$ & $-0.58^{*}$ \\
& $(0.59)$ & $(0.11)$ & $(0.11)$ & $(0.11)$ \\
Border & $2.85^{*}$ & $0.21^{*}$ & $0.23^{*}$ & --- \\
& $(0.06)$ & $(0.02)$ & $(0.02)$ & --- \\
Var $\Delta s(j, k)$ & --- & $0.92^{*}$ & $0.92^{*}$ & -- \\
Adjacent & & $(0.005)$ & $(0.009)$ & --- \\
& --- & -- & $-0.03^{*}$ &
\end{tabular}

Five smallest Border coeffs. (point estimates)

BE-LU $\left(0.11^{*}\right)$

GE-AU $\left(0.18^{*}\right)$

GE-NE $(0.19 *)$

AU-NE $(0.38 *)$

$\operatorname{DE}-\mathrm{LU}\left(0.53^{*}\right)$

IT-SW (3.98*)

Five largest

Border coeffs.

(point estimates)

SP-SW (3.90*)

SW-PO $\left(3.89^{*}\right)$

IT-PO $(2.91 *)$

IT-LU $(2.87 *)$
Adj. $\mathrm{R}^{2}$
.89
.99
.99
.99

Notes: The sample period is 1981:3-1997:7. There are 1485 observations in each regression.

Heteroscedasticity-consistent standard errors are in parenthesis. The dependent variable is the variance of the 1-month change in the log relative price. The independent variables are:

Distance $=$ the distance between cities in the particular pair (in miles);

$\operatorname{Var}(\Delta \mathrm{s}(\mathrm{j}, \mathrm{k}))=$ the variance of the 1-month change in the nominal exchange rate;

Border $=$ unity if the cities in the pair lie across an international border;

Adjacent $=$ unity if there is a common border separating the city pair;

Language $=$ unity if the cities lie in different countries that speak a common language.

Specifications 1-3 also include all 55 individual location dummies (one for each of our 49 cities and one for Austria, Belgium, Denmark, Luxembourg, Netherlands, and Portugal). Specification 4 includes all border dummies as well as all 55 individual location dummies. Mnemonics used for the border dummies are from the following country list: GE=Germany, SP=Spain, IT=Italy, $\mathrm{SW}=$ Switzerland, FR=France, $\mathrm{AU}=$ Austria, BE=Belgium, DE=Denmark, LU=Luxembourg, $\mathrm{NE}=$ Netherlands, and $\mathrm{PO}=$ Portugal. Thus, in specification 4 , for example, the dummy variable IT-SW is unity for location pairs that lie across the Italian-Swiss border and zero for all other location pairs. A (*) indicates the coefficient is significant at the 5\% level.

(1) coefficients and standard error have been multiplied by $10^{4}$; (2) the coefficient and standard error have been multiplied by $10^{7}$; 
Table 3B; Regressions Explaining Relative Price Variability - 48-Month Changes

\begin{tabular}{|c|c|c|c|}
\hline Specification: & 1 & 2 & 3 \\
\hline Distance $^{1}$ & $\begin{array}{l}7.58^{*} \\
0.15)\end{array}$ & 0.46 & $-1.25^{*}$ \\
\hline Distance Squared $^{2}$ & $\begin{array}{l}-3.26^{*} \\
(1.00)\end{array}$ & $\begin{array}{l}-2.09^{*} \\
(0.40)\end{array}$ & $\begin{array}{l}-0.11 \\
(0.19)\end{array}$ \\
\hline Border & $\begin{array}{l}120.8^{*} \\
(8.18)\end{array}$ & $\begin{array}{l}36.8^{*} \\
(4.34)\end{array}$ & --- \\
\hline $\operatorname{Var} \Delta s(j, k)$ & --- & $\begin{array}{l}0.93^{*} \\
(0.03)\end{array}$ & --- \\
\hline Adjacent & --- & $\begin{array}{l}28.8^{*} \\
(6.19)\end{array}$ & --- \\
\hline Language & --- & $\begin{array}{l}-66.2 * \\
(10.8)\end{array}$ & --- \\
\hline Five smallest & & & BE-LU $(5.02 *)$ \\
\hline $\begin{array}{l}\text { Border coeffs. } \\
\text { (point estimates) }\end{array}$ & -- & --- & $\begin{array}{l}\text { BE-FR }\left(5.83^{*}\right) \\
\text { GE-LU }\left(7.73^{*}\right)\end{array}$ \\
\hline & & & $\begin{array}{l}\text { GE-AU }\left(7.93^{*}\right) \\
\text { FR-LU }(8.09 *)\end{array}$ \\
\hline Five largest & & & SP-SW $\left(289.2^{*}\right)$ \\
\hline $\begin{array}{l}\text { Border coeffs. } \\
\text { (point estimates) }\end{array}$ & --- & --- & $\begin{array}{l}\text { IT-SW }\left(266.1^{*}\right) \\
\text { IT-NE }\left(257.1^{*}\right) \\
\text { SP-NE }\left(256.9^{*}\right) \\
\text { IT-PO }\left(248.0^{*}\right)\end{array}$ \\
\hline Adj. $R^{2}$ & .50 & .91 & .99 \\
\hline
\end{tabular}

Notes: The sample period is 1981:3-1997:7. There are 1485 observations in each regression.

Heteroscedasticity-consistent standard errors are in parenthesis. The dependent variable is the variance of the 48-month change in the log relative price. The independent variables are defined in Table 3.

(*) indicates the coefficient is significant at the $5 \%$ level.

(1) coefficients and standard error have been multiplied by $10^{2}$; (2) the coefficient and standard error have been multiplied by $10^{5}$ 
Table 4; Analysis of the Sub-Periods

A. Summary Statistics

Variance $\Delta P(j, k) \quad$ Variance $\Delta s(j, k)$

Pairs: $\quad 81: 3-86: 12 \quad 87: 12-92: 7 \quad 92: 11-97: 7 \quad$ Full $\quad 81: 3-86: 12 \quad 87: 12-92: 7 \quad 92: 11-97: 7 \quad$ Full

\begin{tabular}{cllllllll}
\hline All & 1.59 & 0.77 & 2.27 & 1.78 & 1.24 & 0.40 & 2.06 & 1.25 \\
GE-GE & 0.02 & 0.02 & 0.03 & 0.02 & 0.00 & 0.00 & 0.00 & 0.00 \\
IT-IT & 0.18 & 0.11 & 0.09 & 0.13 & 0.00 & 0.00 & 0.00 & 0.00 \\
SP-SP & 0.32 & 0.28 & 0.05 & 0.22 & 0.00 & 0.00 & 0.00 & 0.00 \\
SW-SW & 0.11 & 0.06 & 0.03 & 0.07 & 0.00 & 0.00 & 0.00 & 0.00 \\
$\begin{array}{c}\text { Intra- } \\
\text { national }\end{array}$ & 0.22 & 0.16 & 0.07 & 0.16 & 0.00 & 0.00 & 0.00 & 0.00 \\
$\begin{array}{c}\text { Inter- } \\
\text { national }\end{array}$ & 2.30 & 1.06 & 3.65 & 2.69 & 2.18 & 0.71 & 3.62 & 2.52 \\
\hline \hline
\end{tabular}

B. Regressions Explaining Relative Price Variability

\begin{tabular}{cccc}
\hline \hline Specification: & 1 & 2 & 3 \\
\hline Distance $^{1}$ & $3.31^{*}$ & 0.30 & $0.76^{*}$ \\
& $(1.00)$ & $(0.30)$ & $(0.26)$ \\
Distance Squared $^{2}$ & $1.08^{*}$ & 0.05 & $-0.34^{*}$ \\
& $(0.47)$ & $(0.17)$ & $(0.14)$ \\
Border & $0.76^{*}$ & $0.07^{*}$ & --- \\
& $(0.05)$ & $(0.02)$ & --- \\
Var $(\Delta$ s $(\mathrm{j}, \mathrm{k}))$ & --- & $1.24^{*}$ & BE-LU $\left(0.09^{*}\right)$ \\
& & $(0.03)$ & GE-BE $\left(0.11^{*}\right)$ \\
Five smallest & --- & $\left.---11^{*}\right)$ \\
border coeffs. & & & GE-LU $\left(0.11^{*}\right)$ \\
(point estimates) & & & FR-BE $\left(0.11^{*}\right)$ \\
& & & GE-NE $\left(0.14^{*}\right)$ \\
Five largest & --- & & SP-SW $\left(2.64^{*}\right)$ \\
border coeffs. & & & SP-NO $\left(2.37^{*}\right)$ \\
(point estimates) & & & SW-AU $\left(1.50^{*}\right)$ \\
& & & SW-NE $\left(1.44^{*}\right)$ \\
\hline Adj. R ${ }^{2}$ & .79 & .98 & .99 \\
\hline \hline
\end{tabular}

Notes: See notes to Table 3. All results are for one-month changes. The sample period for the regressions of panel B is 1987:12-1992:7. 
Table 5; Regression Results using Disaggregated (National) Data

\begin{tabular}{|c|c|c|c|c|}
\hline Good: & $\operatorname{Var} \Delta s(j, k)$ & Adj. R-sq. & Countries & Dates \\
\hline Food & $\begin{array}{c}1.05 \\
(0.17)\end{array}$ & .92 & $\overline{\mathrm{i}}$ & $\mathrm{a}$ \\
\hline Clothing and Footwear & $\begin{array}{c}1.40 \\
(0.22)\end{array}$ & .91 & $\mathrm{i}$ & $\mathrm{a}$ \\
\hline Rents & $\begin{array}{c}0.73 \\
(0.33)\end{array}$ & .92 & $\mathrm{i}$ & $\mathrm{a}$ \\
\hline Household Equipment & $\begin{array}{c}1.16 \\
(0.23)\end{array}$ & .92 & $\mathrm{i}$ & $\mathrm{a}$ \\
\hline Meat & $\begin{array}{c}0.83 \\
(0.14)\end{array}$ & .90 & $\mathrm{i}$ & $\mathrm{b}$ \\
\hline Footwear & $\begin{array}{c}1.01 \\
(0.11)\end{array}$ & .96 & $\mathrm{i}$ & $\mathrm{b}$ \\
\hline Hotels & $\begin{array}{c}0.87 \\
(0.15)\end{array}$ & .91 & $\mathrm{i}$ & $\mathrm{b}$ \\
\hline Furniture & $\begin{array}{c}0.85 \\
(0.13)\end{array}$ & .93 & $\mathrm{i}$ & $\mathrm{c}$ \\
\hline Fuel and Energy & $\begin{array}{c}0.41 \\
(0.17)\end{array}$ & .81 & $\mathrm{i}$ & $\mathrm{d}$ \\
\hline Breads and Cereals & $\begin{array}{c}0.80 \\
(0.17)\end{array}$ & .93 & ii & $\mathrm{b}$ \\
\hline Drinks & $\begin{array}{c}0.83 \\
(0.27)\end{array}$ & .97 & iii & $\mathrm{b}$ \\
\hline Clothing & $\begin{array}{c}1.08 \\
(0.14)\end{array}$ & .94 & iii & $\mathrm{b}$ \\
\hline Domestic Appliances & $\begin{array}{c}1.01 \\
(0.13)\end{array}$ & .96 & iii & $\mathrm{c}$ \\
\hline Dairy Products & $\begin{array}{c}0.91 \\
0.13)\end{array}$ & .94 & iv & $\mathrm{b}$ \\
\hline Fruit & $\begin{array}{c}0.25 \\
(0.45)\end{array}$ & .82 & iv & $\mathrm{b}$ \\
\hline Recreation & $\begin{array}{c}1.61 \\
(0.17)\end{array}$ & .96 & iv & $\mathrm{a}$ \\
\hline Vehicles & $\begin{array}{c}0.85 \\
(0.10)\end{array}$ & .98 & $\mathrm{v}$ & $\mathrm{b}$ \\
\hline Sound and Photographic Equipment & $\begin{array}{c}1.09 \\
(0.11)\end{array}$ & .96 & $\mathrm{v}$ & $\mathrm{b}$ \\
\hline Books & $\begin{array}{c}1.42 \\
(0.25)\end{array}$ & .94 & vi & $\mathrm{b}$ \\
\hline
\end{tabular}

Notes: The dependent variable is the variance of the 12-month change in the log relative price. Each regression includes individual country dummies, distance, distance squared, and an adjacency dummy (estimates not displayed), in addition to the variance of the 12month change in the nominal exchange rate. The sample periods are: (a) 1977:1-95:12, (b) 1981:1-95:7, (c) 81:1-94:10, (d) 1980:1-95:7. The countries included in the sample are Belgium, Germany, France, Italy, and the U.K., plus: (i) Denmark, Spain, Netherlands, Portugal; (ii) Denmark, Spain, and Portugal; (iii) Spain, Netherlands, and Portugal; (iv) Denmark, Spain, and Netherlands, (v) Spain and Netherlands, and (vi) Denmark and Netherlands. 


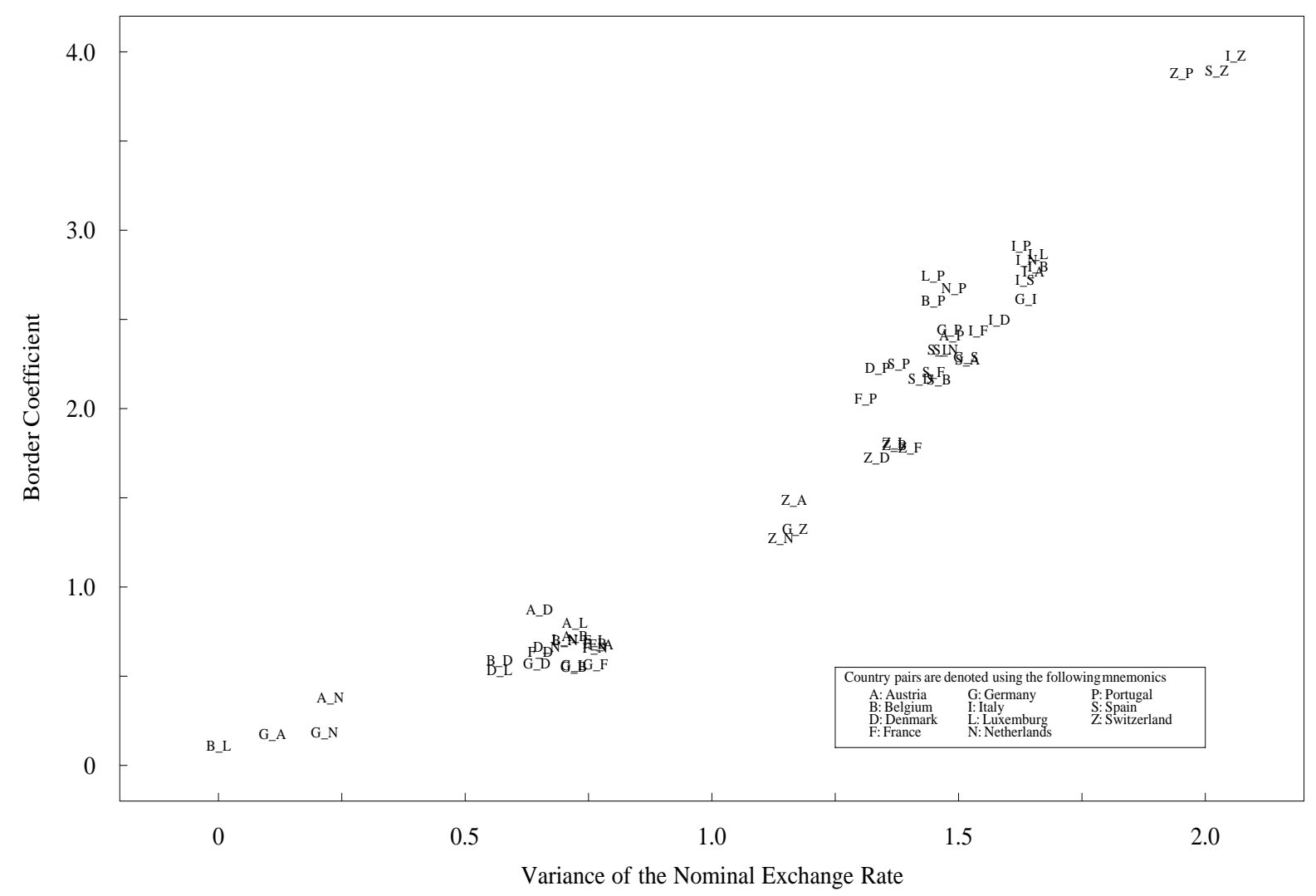

Figure 1: Estimated Border Coefficient vs. Exchange Rate Variability. On the vertical axis is the coefficient estimate on the individual border dummies in specification 3 of Table 3 . The horizontal axis depicts the variance of the one-month change in the nominal exchange rate. 


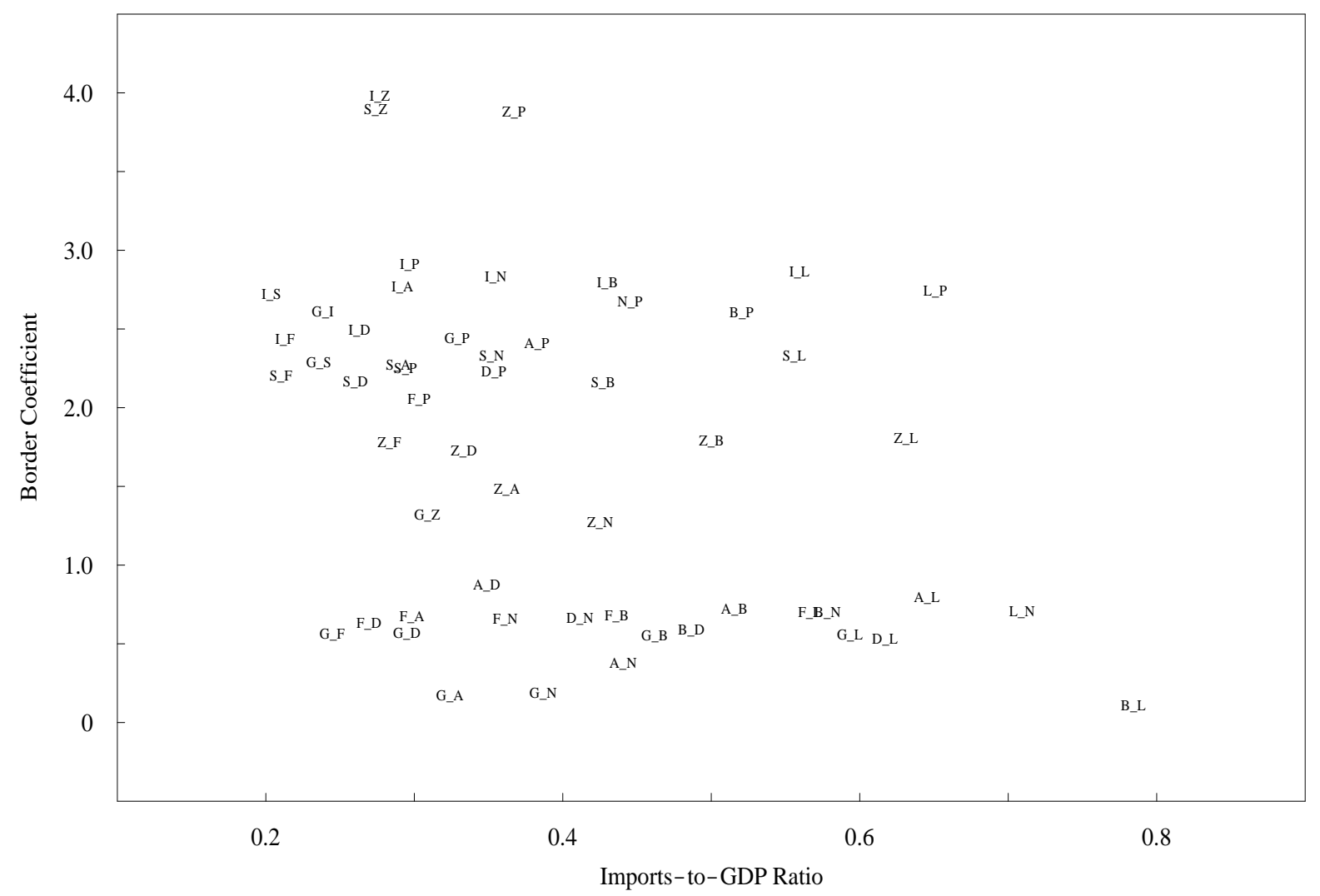

Figure 2: Estimated Border Coefficient vs. Import/GDP Ratio. Along the vertical axis is the coefficient estimate on the individual border dummies in specification 3 of Table 3 . The horizontal axis depicts the average ratio of imports to GDP. 